\title{
Sistem Informasi Penjualan Barang Furniture Berbasis Web Pada PT. Vinotindo Graha Sarana Menggunakan PHP dan MySQL
}

\author{
Anik Sri Wahyuningsih ${ }^{1}$, Anjar Imam Bahron ${ }^{2}$ \\ 1,2Program Studi Sistem Informasi STMIK Cikarang \\ ${ }^{1,2}$ Jl. Kapten Sumantri No. 16 Cikarang - Bekasi \\ *1anik_naufal@yahoo.com, ${ }^{2}$ anjarimb@gmail.com
}

\begin{abstract}
Abstraksi- Perkembangan dunia internet sekarang ini sangat pesat, karena semakin banyak perusahaan swasta, instansi pemerintahan dan istitusi pendidikan membutuhkan layanan informasi yang sangat cepat.. Sistem penjualan banyak dilakukan secara online, sehingga mempermudah pelanggan. Dalam penelitian ini akan membuat Sistem Informasi Penjualan Barang Furniture berbasis Web pada PT. Vinotindo Graha Sarana. Saat ini masih menggunakan sistem penjualan secara manual, sehingga pelanggan kurang mendapatkan informasi yang akurat dan cepat. Karena pelanggan harus datang ke PT. Vinotindo Graha Sarana untuk mendapat informasi dan melakukan pemesana, selaim itu membutuhkan waktu yang lama dalam transaksi penjualan. Diharapkan dengan sistem penjualan berbasis web akan meningkatkan penjualan dan mempermudah transaksi penjualan dengan pelanggan.
\end{abstract} MySQL

Kata Kunci- Sistem Informasi, Furniture, UML, PHP,

\section{PENDAHUluaN}

Dalam memasuki dunia globalisasi, manusia mengenal teknologi yang semakin maju untuk mempermudah melakukan berbagai kegiatan dalam kehidupan. Kemajuan di bidang transportasi, komunikasi, kesehatan, pendidikan, dan bidang lainnya merupakan contoh-contoh bahwa manusia semakin memerlukan teknologi dalam kehidupan ini. Saat ini dunia telah mengenal suatu teknologi yang disebut dengan internet. Dengan internet semua orang dapat berkomunikasi dengan orang lain yang berada di berbagai belahan dunia. Melalui internet setiap orang dapat memperoleh dan menyampaikan berbagai infromasi yang dibutuhkan kapan saja dan dimana saja.

Kini dengan hadirnya internet, manusia dapat melakukan bisnis lebih mudah. PT. Vinotindo Graha Sarana merupakan perusahaan yang bergerak di bidang produksi dan penjualan furniture, belum ada penjualan secara online. Calon pembeli melakukan pembelian melalui telepon, email atau datang langsung ke perusahaan yang kemudian diproses secara manual oleh admin perusahaan ini. PT. Vinotindo Graha Sarana mengalami kesulitan dalam pengelolaan transaksi dalam jumlah banyak secara manual. Dan menyebabkan proses pembuatan laporan Pemesanan dan penjualan membutuhkan waktu yang relatif lama, karena harus membuat rekapitulasi dari dokumen-dokumen transaksi tersebut.

Berdasarkan penjelasan diatas penulis tertarik mengambil penelitian dengan judul "SISTEM INFORMASI PENJUALAN BARANG FURNITURE BERBASIS WEB PADA PT. VINOTINDO GRAHA SARANA MENGGUNAKAN PHP DAN MYSQL".

Berdasarkan latar belakang masalah, dapat diidentifikasi permasalahannya adalah bagaimana menerapkan Sistem Informasi penjualan Barang Furniture Berbasis Web pada PT. Vinotindo Graha. Kemudian juga bagaimana keakuratan data penjualan dan laporannya.

Adapun pembatasan masalah dalam pembahasan penelitian ini adalah penelitian ini membahas mengenai Sistem Informasi Penjualan barang Furniture Berbasis Web Pada PT. Vinotindo Graha dan bahasa Pemrograman yang digunakan PHP dan MySQL.

\section{LANDASAN TEORI}

\section{A. Pengertian Sistem}

Istilah kata sistem berasal dari bahasa Yunani (sustema) yang memiliki arti suatu perusahaan bermacam-macam hal menjadi suatu keseluruhan dengan bagian-bagian yang tersusun dari dalam. Dalam suatu sistem, masing-masing unit dan keseluruhannya sebagai kesatuan saling bergantung, saling menentukan dan membutuhkan.

\section{Berikut pengertian Sistem menurut para ahli :}

"Sistem adalah suatu kumpulan atau himpunan dari unsur, komponen, atau variabel yang terorganisasi, saling berinteraksi, saling tergantung satu sama lain dan terpadu." [11].

"Sistem adalah kumpulan dari elemen-elemen yang berinteraksi untuk mencapai suatu tujuan tertentu sebagai satu kesatuan." [9].

"Sistem adalah hubungan satu unit dengan unit-unit lainnya yang saling berhubungan satu sama lainnya dan yang tidak 
dapat dipisahkan serta menuju satu kesatuan dalam rangka mencapai tujuan yang ditetapkan. Apabila suatu unit macet atau terganggu, unit lainnya pun akan terganggu untuk mencapai tujuan yang telah ditetapkan tersebut. "[6].

\section{B. Pengertian Informasi}

Telah diketahui bahwa informasi merupakan hal yang sangat penting bagi manajemen dalam pengambilan keputusan. Beberapa ahli mendefinisikan informasi sebagai berikut :

"Informasi adalah data yang diolah menjadi bentuk yang lebih berguna dan lebih berarti bagi yang menerimanya, sedangkan data merupakan sumber infromasi yang menggambarkan suatu kejadian yang nyata." [9].

"Informasi adalah data yang telah diproses atau diolah ke dalam bentuk yang berarti untuk penerimanya dan merupakan nilai yang sesungguhnya atau dipahami dalam tindakan atau keputusan yang sekarang nantinya." [6].

"Informasi adalah data yang diolah menjadi bentuk yang berguna bagi para pemakainya." [4].

\section{Pengertian Penjualan}

Penjualan merupakan pembelian sesuatu (barang atau jasa) dari suatu pihak kepada pihak lainnya dengan mendapatkan ganti uang dari pihak tersebut. Penjualan juga merupakan suatu sumber pendapatan perusahaan, semakin besar penjualan maka semakin besar pula pendapatan yang diperoleh perusahaan.

"Penjualan adalah pendapatan lazim dalam perusahaan dan merupakan jumlah kotor yang dibebankan kepada pelanggan ataas barang dan jasa" [10].

"Penjualan artinya penjualan barang dagangan sebagai usaha pokok perusahaan yang biasanya dilakukan secara teratur" [7].

\section{RANCANGAN SISTEM DAN APLIKASI}

\section{A. Analisa Kebutuhan Sistem}

Pelanggan yang ingin membeli produk tidak harus lagi datang ke pabrik untuk bertemu dengan bagian Marketing ataupun melakukan pemesanan barang melalui telepon ke bagian marketing, tapi sudah lebih mudah untuk melakukan pemesanan barang melalui website. Berikut rincian prosedur yang diusulkan diantaranya :

\section{1) Prosedur Konsumen}

Prosedur yang diusulkan pada konsumen yang sudah dapat diakses kapan dan dimana saja untuk melakukan order barang yang sudah tidak lagi harus datang ke pabrik.

\section{2) Prosedur Admin}

Prosedur yang diusulkan pada admin untuk mengecek laporan transaksi penjualan hanya melalui halaman admin.

\section{B. Analisis Sistem Usulan}

1) Use Case Diagram Usulan

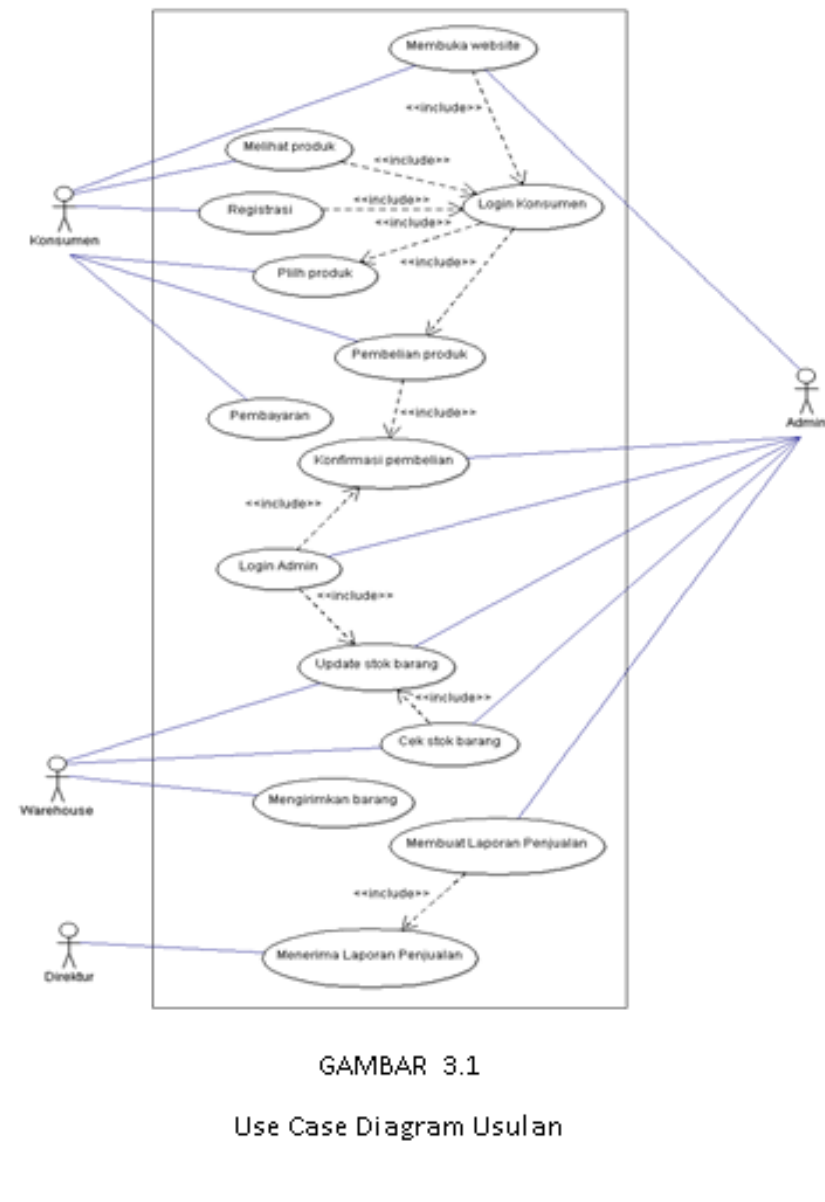

2) Activity Diagram Usulan

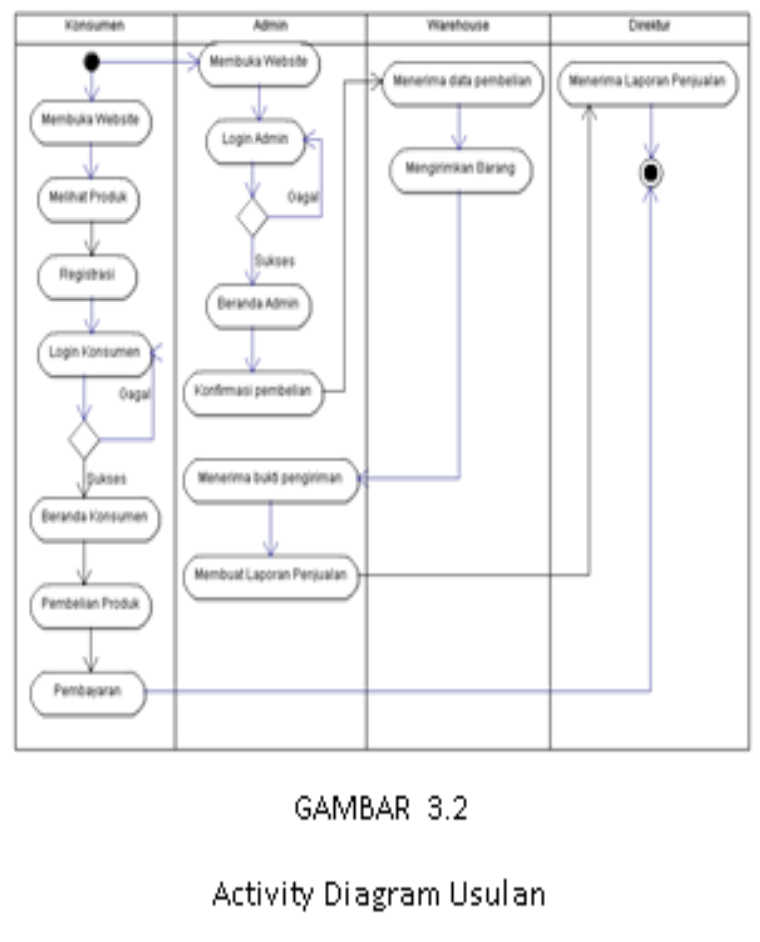


3) Sequence Diagram Login

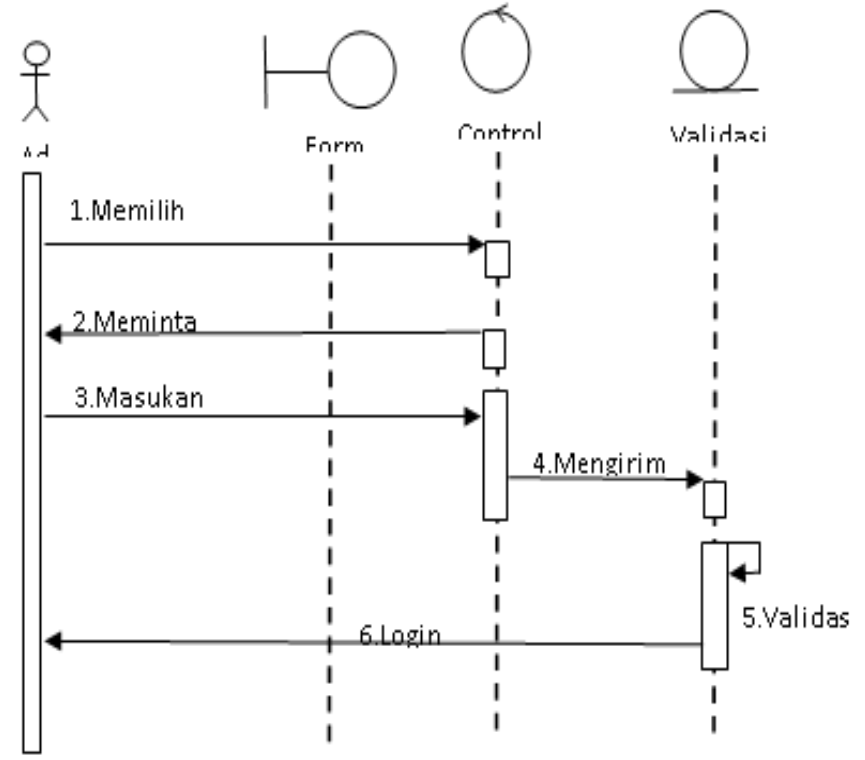

GAMBAR 3.3

Sequence Diagram
5) Class Diagram

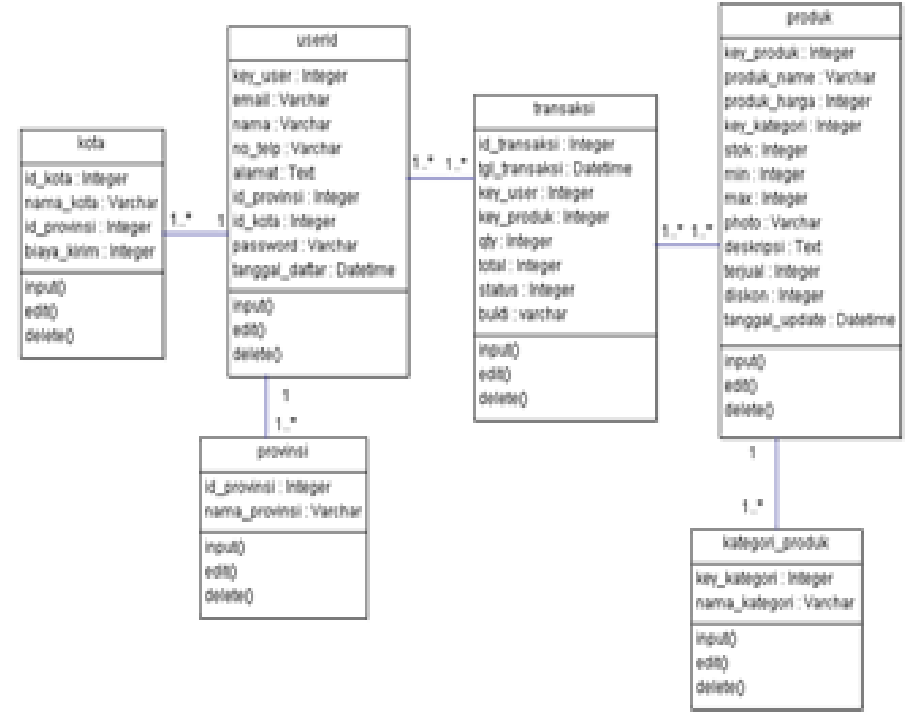

GAMBAR 3.5

Class Diagram
4) Sequence Diagram Input Produk

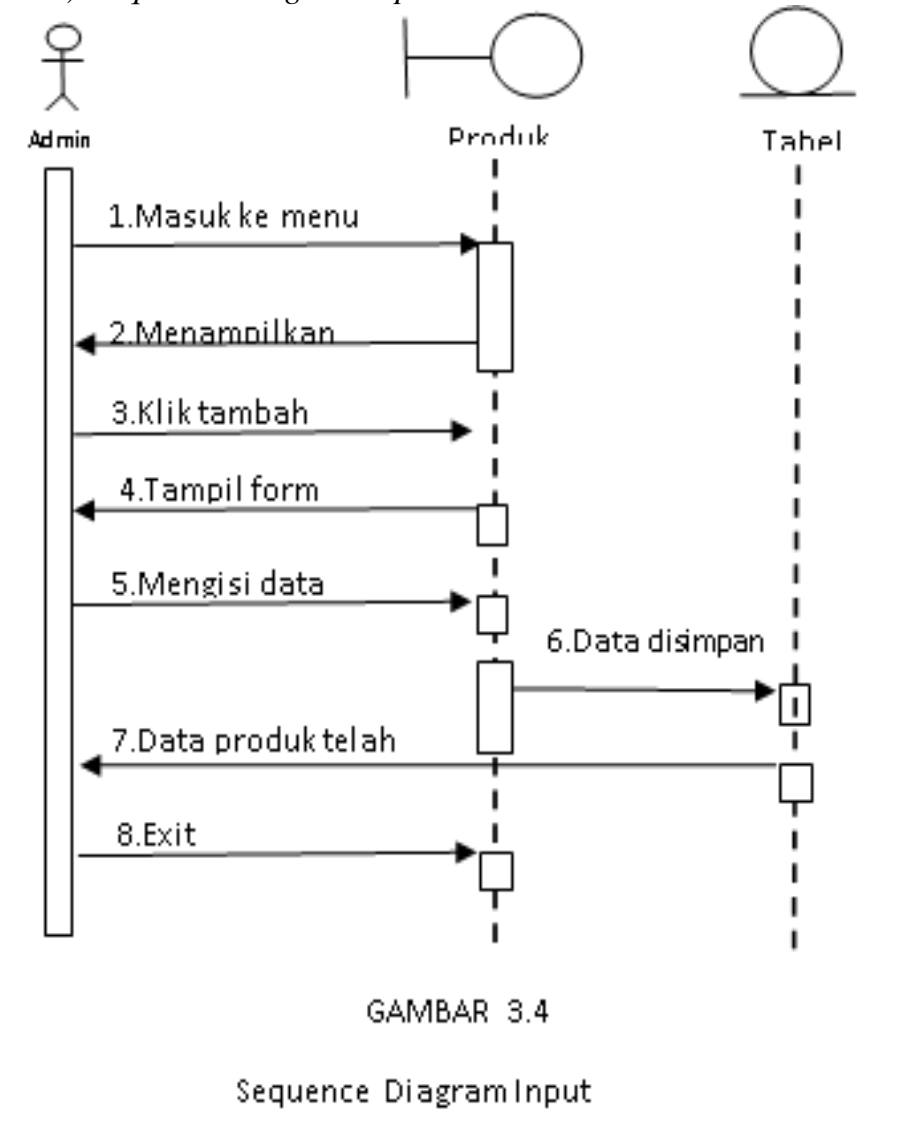

6) Rancangan Menu Utama

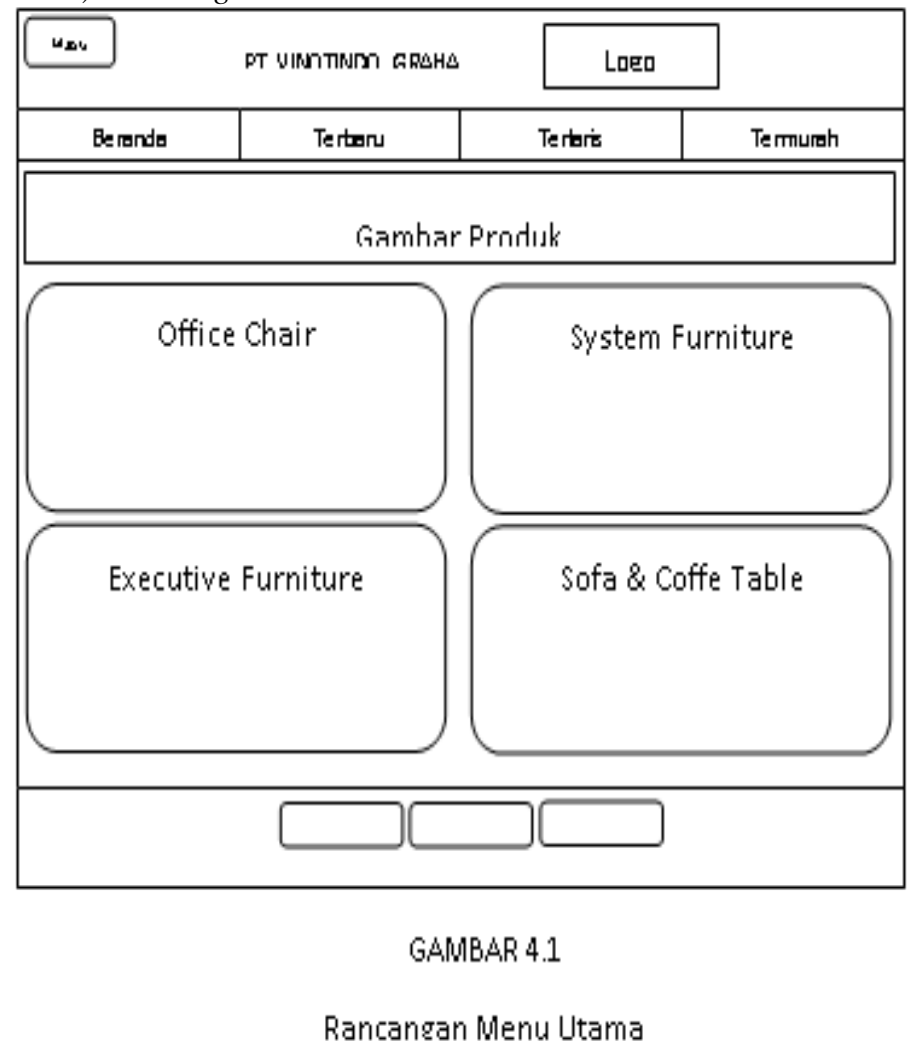


IV. HASIL DAN PEMBAHASAN

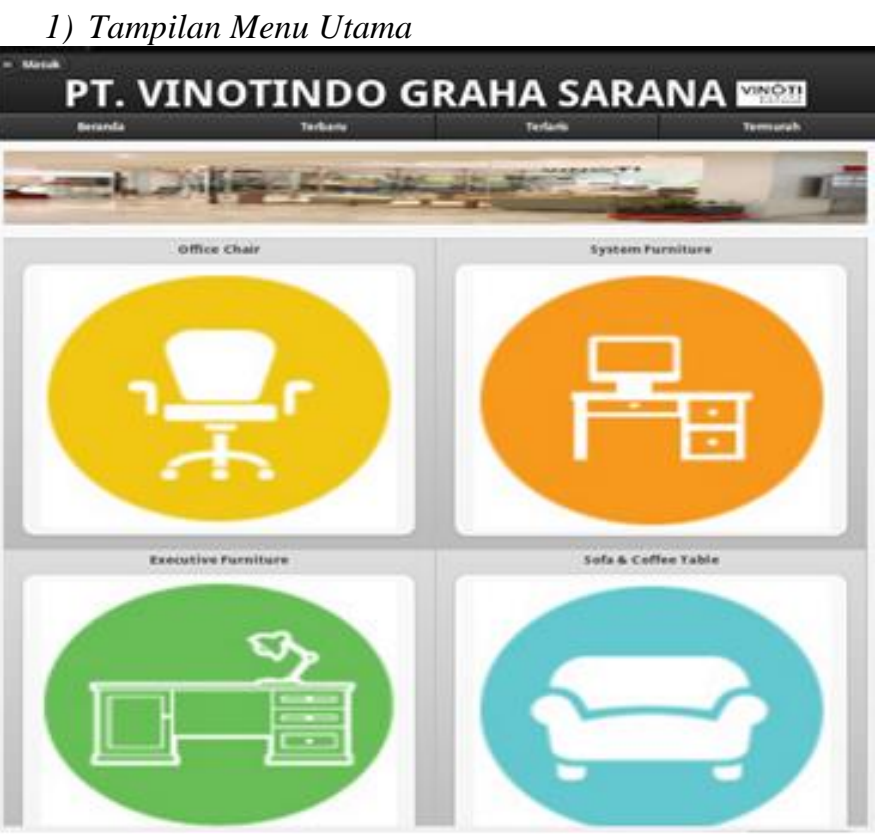

GAMBAR 4.1 Tampilan Menu Utama

2) Tampilan Menu Login

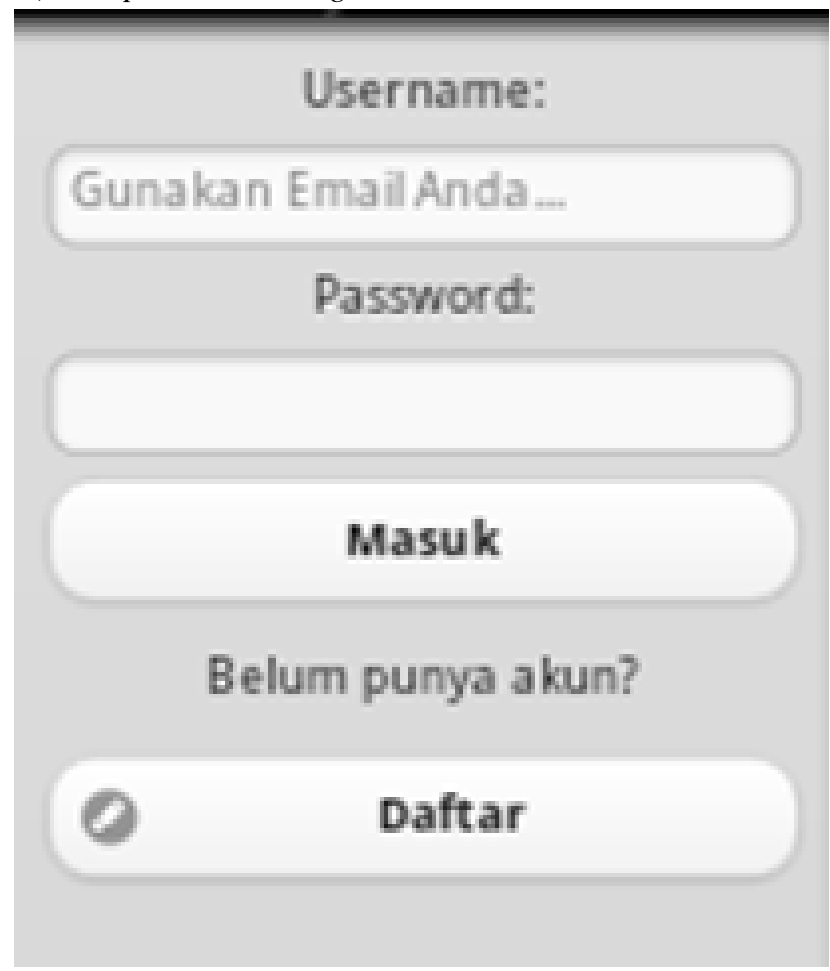

GAMBAF 4.2 Tampilan Menu Login

\section{3) Tampilan Menu Daftar Konsumen}

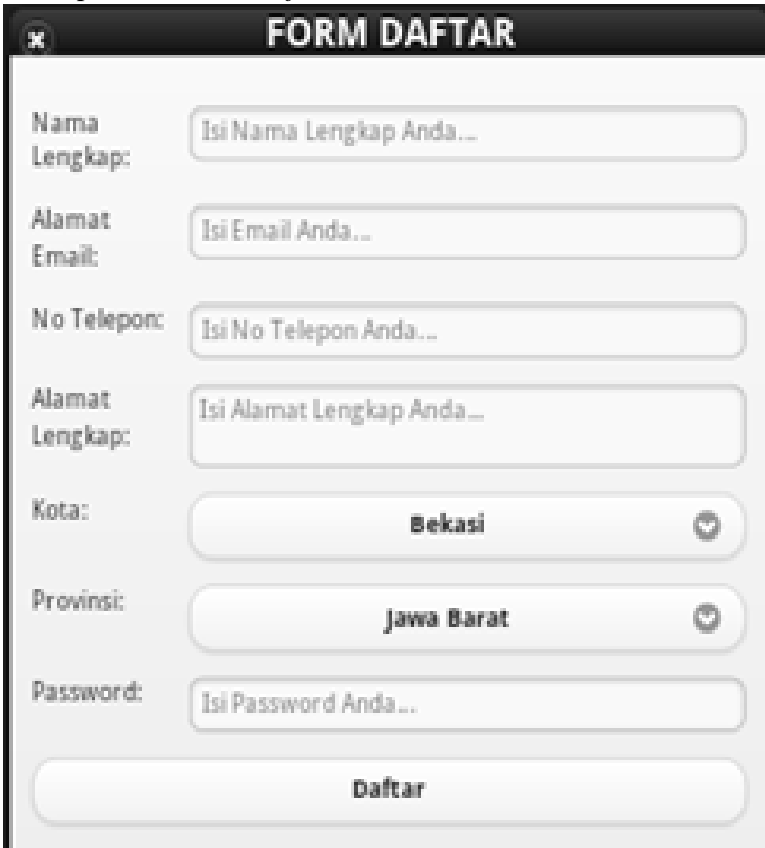

GAMBAR 4.3 Tampilan Menu Daftar Konsumen

4) Tampilan Menu Input Produk

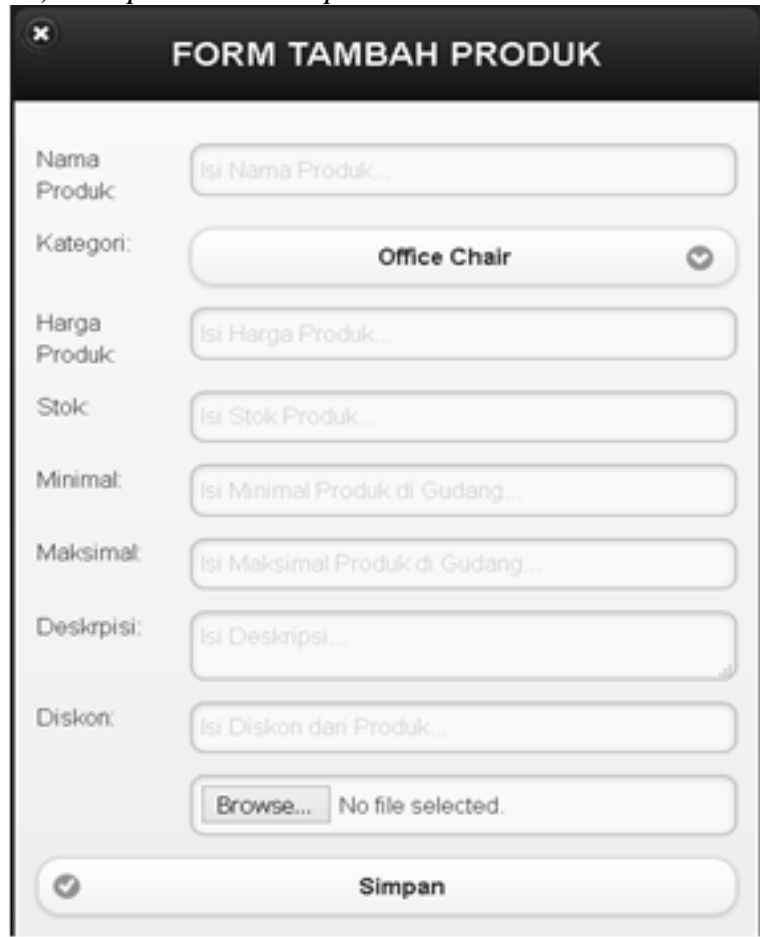

GAMBAR 4.4 Tampilan Menu Input Produk 


\section{KESIMPULAN}

Dari seluruh pokok pembahasan pada bab-bab sebelumnya, maka secara umum dapat penulis simpulkan sebagai berikut :

- Sistem Informasi Penjualan Barang Furniture pada PT. Vinotindo Graha Sarana meliputi pemesanan dan penjualan secara online, sehingga memudahkan konsumen.

- Pada setiap transaksi penjualan barang furniture bisa langsung dibuat laporan, sehingga memudahkan dan mempercepat pembuatan laporan penjualan pada setiap transaksi.

\section{DAFTAR PUSTAKA}

[1] Abadi, andalan prima. http://www.andalanprimaabadi.com/articles/artidan-bentukfurniture/, dipublikasikan tanggal 14 Maret 2010.
[2] Ardhana, YM Kusuma. 2012. PHP Menyelesaikan Website 30 Juta Rupiah. Jasakom.

[3] Hidayatullah Priyanto, dan Khairul Kawistara. 2014. Pemrograman Web. Bandung. Informatika.

[4] Jogiyanto. 2009. Sistem Teknologi Informasi. Pendekatan Terintegrasi, Konsep Dasar Teknologi, Aplikasi, pengembangan dan pengelolaan. Yogyakarta: Andi Offset.

[5] Kadir, Abdul. 2011. Buku Pintar JQuery dan PHP. Yogyakarta: MediaKom.

[6] L.Gaol, Chr. Jimmy. 2008. Sistem Informasi Manajemen Pemahaman dan Aplikasi. Jakarta: Grasindo.

[7] Marom, Chairul. 2009. Manajemen Penjualan. Yogyakarta: Liberty.

[8] Mulhim, Imam. 2014. Web Mobile untuk Orang Awam. Maxikom.

[9] Mulyanto, Agus. 2009. Sistem Informasi Konsep \& Aplikasi. Yogyakarta: PUSTAKA PELAJAR.

[10] Simamora, Henry. 2013. Akuntansi Manajemen Edisi III. Yogyakarta: Diandra Primatirta.

[11] Subtari, Tata. 2012. Konsep Sistem Informasi. Yogyakarta: Andi Offset.

[12] Sumarni Murti., dan John Suprihatno. 2014. Pengantar Bisnis (dasardasar ekonomi perusahaan). Yogyakarta: Liberty. 